\title{
2D ANALYSIS OF STRESSES AND DISPLACEMENTS OF ROLLER COMPACTED CONCRETE PAVEMENTS (RCCP) FOR LOW VOLUME ROADS UNDER VEHICULAR LOADING
}

\author{
P.Vineela ${ }^{1}$, S.Krishna Rao ${ }^{2}$, B.Panduranga $\operatorname{Rao}^{3}$, V.Ramesh ${ }^{4}$ \\ ${ }^{1}$ M.Tech Student, Civil Engineering Department, V.R.Siddhartha Engineering College, Andhra Pradesh, India \\ ${ }^{2}$ Associate Professor, Civil Engineering Department, V.R.Siddhartha Engineering College, Andhra Pradesh, India \\ ${ }^{3}$ Professor, Civil Engineering Department, V.R.Siddhartha Engineering College, Andhra Pradesh, India \\ ${ }^{4}$ Associate Professor, Civil Engineering Department, V.R.Siddhartha Engineering College, Andhra Pradesh, India
}

\begin{abstract}
The American Concrete Institute (ACI) $116 \mathrm{R}$ defines RCC as "Concrete compacted by roller compaction; concrete that in its unhardened state will support a roller while being compacted”. RCC as a pavement material has been gaining acceptance over the past years. RCC can combat the problems often encountered with flexible bituminous pavements. RCC is the commercial name used for concrete placed with conventional hot mix bituminous paving equipment then compacted with vibratory rollers. This early stiffness makes the compaction process of RCC a feasible construction method and therefore eliminates the need for forms, finishing, dowels and steel reinforcement. The main objective of pavement design is to calculate the optimal thickness of different structural layers. In the design of rigid pavements, it is important to determine the thickness of slab in case of rigid slab taking most of the load carrying capacity. Roller Compacted Concrete Pavement belongs to the family of rigid pavements. Therefore the methods used for jointed plain concrete pavements are used for analyzing and designing of Roller Compacted Concrete Pavement. These methods primarily depend on "WESTERGAARD's" analytical solution, which determines the mechanical response of a concrete slab under vehicular loading. Analysis of rigid pavements consists of determination of stresses, strains and displacements in a slab induced by vehicular and/or environmental loading. The model pavement will be analyzed under a tire load of $30 \mathrm{kN}$ with tire pressure of $0.5 \mathrm{~N} / \mathrm{mm}^{2}$, tire load of $51 \mathrm{kN}$ with a tire pressure of $0.7 \mathrm{~N} / \mathrm{mm}^{2}$, tire load of $65 \mathrm{kN}$ with a tire pressure of $0.74 \mathrm{~N} / \mathrm{mm}^{2}$; applied at three different locations namely, the pavement center, the pavement corner and the pavement edge using ALIZE, IAONNIDES and PORTLAND CEMENT ASSOCIATION (PCA) equations. For the applied tire load relative stresses and displacements will be calculated at three different locations. IRC: SP-62-2004 guidelines have been followed.
\end{abstract}

Keywords: Wheel Load, Roller Compacted Concrete Pavement, Tire Pressure, Modulus of Sub grade Reaction.

\section{INTRODUCTION}

Roller Compacted Concrete is the commercial name used for concrete placed with conventional hot-mix asphalt paving equipment, then compacted with rollers[5]. The basic ingredients used for conventional concrete are used for $\mathrm{RCC}$; but RCC is a drier mix made with low water-cement ratio, but with same cement content as that of a conventional concrete. Therefore, RCC is well renowned as a "ZEROSLUMP" concrete. Hence, there will be early stiffness in the concrete \& thus the compaction process of RCC is quite easier compared to conventional concrete \& thus construction of RCC pavements is simple, fast \& economical. In addition, RCC pavements are highly rigid, due to this reason; there is no problem of deformation that usually occurs in flexible pavements.

The main objective of pavement design is to calculate the optimal thickness of its different structural layers; therefore several design methods for rigid pavements were developed to determine the necessary concrete slab thickness[8]. Determination of the pavement response to vehicular loadings evolved also over time from using simple closedform formulae, to the use of influence charts, to the use of finite-element method.

\section{APPLICATION OF 2D MODELS FOR}

\section{ANALYSIS OF RCC PAVEMENTS}

Analysis of rigid pavements includes determination of stresses, strains \& displacements in the slab induced due to vehicular and/or environmental loadings. The first theoretical solutions to the problem of a tire load on a concrete slab laid over a supporting sub grade were proposed by Westergaard in early 1920's[9]. Further research was carried out by some other researchers \&Westergaard's solutions were further developed \& some more closed-form formulae \& influence charts were presented to solve the $2 \mathrm{D}$ problem shown in below figure[10,11,12]. 


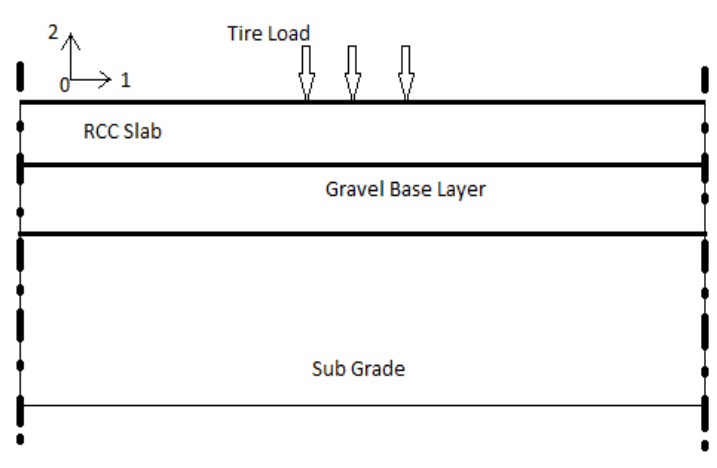

Fig. 1 2D Model Adopted for a RCC Pavement under a Tire Load

\subsection{Corner Loading}

In case of corner loading, on bottom surface of slab, the equations proposed by Westergaard to calculate the tensile stress $(\sigma) \&$ vertical displacement $(\Delta)$ are:

$$
\begin{aligned}
& \sigma=\frac{3 P}{h^{2}}\left[1-\left(\frac{\mathrm{a} \sqrt{2}}{1}\right)^{0.6}\right] \\
& \Delta=\frac{P}{k l^{2}}\left[1.1-0.88\left(\frac{\mathrm{a} \sqrt{2}}{1}\right)\right]
\end{aligned}
$$

Where, ' $\mathrm{l}$ ' is radius of relative stiffness $(\mathrm{m})$ given by equation (3), ' $\mathrm{a}$ ' is the contact radius ( $\mathrm{m})$, ' $\mathrm{P}$ ' is the concentrated load $(\mathrm{N})$, ' $h$ ' thickness of RCC slab (m), ' $k$ ' is the modulus of sub grade reaction $(\mathrm{MPa} / \mathrm{m})$;

$$
1=\left[\frac{E h^{3}}{12\left(1-v^{2}\right) k}\right]^{0.25}
$$

Where, ' $\mathrm{E}$ ' is elastic modulus of RCC slab, ' $\mathrm{v}$ ' is Poisson's ratio

Further research was carried \&Westergaard's (1926) equations were modified by Ioannides (1985) \& he suggested the equations;

$$
\begin{aligned}
& \sigma=\frac{3 P}{h^{2}}\left[1-\left(\frac{\mathrm{c}}{\mathrm{l}}\right)^{0.72}\right] \\
& \Delta=\frac{P}{k l^{2}}\left[1.205-0.69\left(\frac{\mathrm{c}}{\mathrm{l}}\right)\right]
\end{aligned}
$$

Where, $\mathrm{c}=1.772 * \mathrm{a}$

A comparison was made between these different equations presented by Westergaard[9] (1926) \&Ioannides[10] (1985) with three different load cases:

Case (I): A tire load of $\mathrm{P}=30 \mathrm{kN}$, with a tire pressure[13] of $0.5 \mathrm{~N} / \mathrm{mm}^{2}$

Case (II): A tire load of $\mathrm{P}=51 \mathrm{kN}$, with a tire pressure of $0.7 \mathrm{~N} / \mathrm{mm}^{2}$

Case (III): A tire load of $\mathrm{P}=65 \mathrm{kN}$, with a tire pressure of $0.74 \mathrm{~N} / \mathrm{mm}^{2}$

And in common, having a slab thickness of $\mathrm{h}=0.20 \mathrm{~m}$, three cases for the modulus of sub grade reaction $(\mathrm{k}=21,62,140)$ and calculated stress \& deformation were tabulated in

\begin{tabular}{|c|c|c|c|c|}
\hline \multicolumn{5}{|c|}{ Case (II): } \\
\hline Wheel Load & $(\mathrm{N})$ & 51000 & & \\
\hline$E_{\text {FOUNDATION }}$ & $(\mathrm{MPa})$ & 30 & 150 & 500 \\
\hline CBR & & 2 & 15 & 50 \\
\hline$E_{R C C}$ & $(\mathrm{MPa})$ & 30000 & 30000 & 30000 \\
\hline $\mathrm{k}$ & $(\mathrm{MPa} / \mathrm{m})$ & 21 & 62 & 140 \\
\hline 1 & $(\mathrm{~m})$ & 1.0 & 0.762 & 0.622 \\
\hline$\sigma_{W E S T E R G A R D S}$ & (MPa) & 2.30 & 2.03 & 1.80 \\
\hline$\sigma_{\text {Ioannides }}$ & (MPa) & 2.33 & 2.01 & 1.73 \\
\hline$\Delta_{W E S T E R G A R D S}$ & $(\mathrm{~mm})$ & 2.2 & 1.2 & 0.74 \\
\hline$\Delta_{\text {Ioannides }}$ & $(\mathrm{mm})$ & 2.4 & 1.36 & 0.85 \\
\hline
\end{tabular}
table1.

Table-1: Stresses and displacements for the corner loading case using Westergaard and Ioannides equations

Case (I):

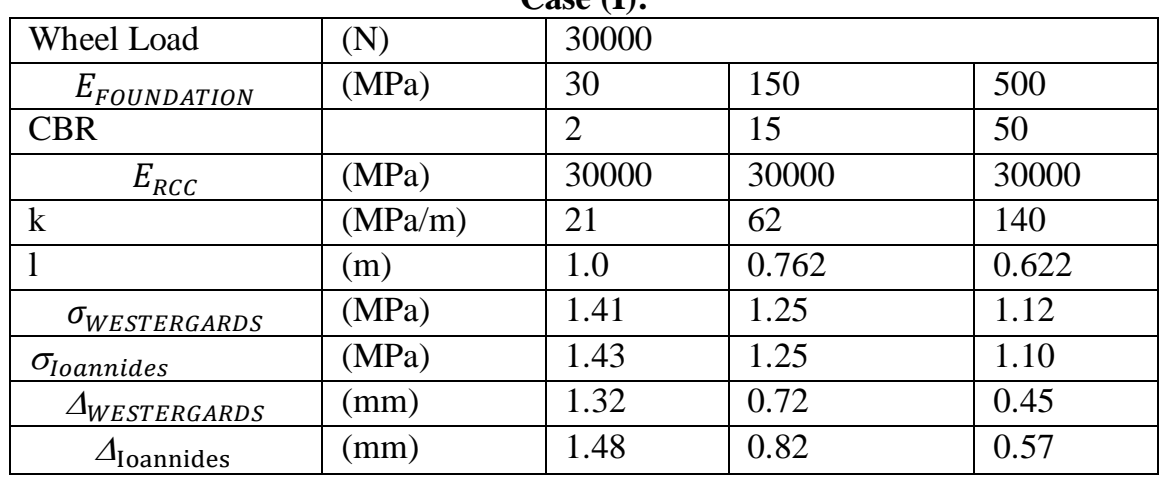




Case (III):
\begin{tabular}{|l|l|l|l|l|}
\hline Wheel Load & $(\mathrm{N})$ & 65000 & \\
\hline$E_{\text {FOUNDATION }}$ & $(\mathrm{MPa})$ & 30 & 150 & 500 \\
\hline CBR & & 2 & 15 & 50 \\
\hline$E_{R C C}$ & $(\mathrm{MPa})$ & 30000 & 30000 & 30000 \\
\hline $\mathrm{k}$ & $(\mathrm{MPa} / \mathrm{m})$ & 21 & 62 & 140 \\
\hline 1 & $(\mathrm{~m})$ & 1.0 & 0.762 & 0.662 \\
\hline$\sigma_{\text {WESTERGARDS }}$ & $(\mathrm{MPa})$ & 2.82 & 2.46 & 2.24 \\
\hline$\sigma_{\text {IOannides }}$ & $(\mathrm{MPa})$ & 2.84 & 2.41 & 2.15 \\
\hline$\Delta_{\text {WESTERGARDS }}$ & $(\mathrm{mm})$ & 2.7 & 1.49 & 0.83 \\
\hline$\Delta_{\text {Ioannides }}$ & $(\mathrm{mm})$ & 3.09 & 1.66 & 0.95 \\
\hline
\end{tabular}

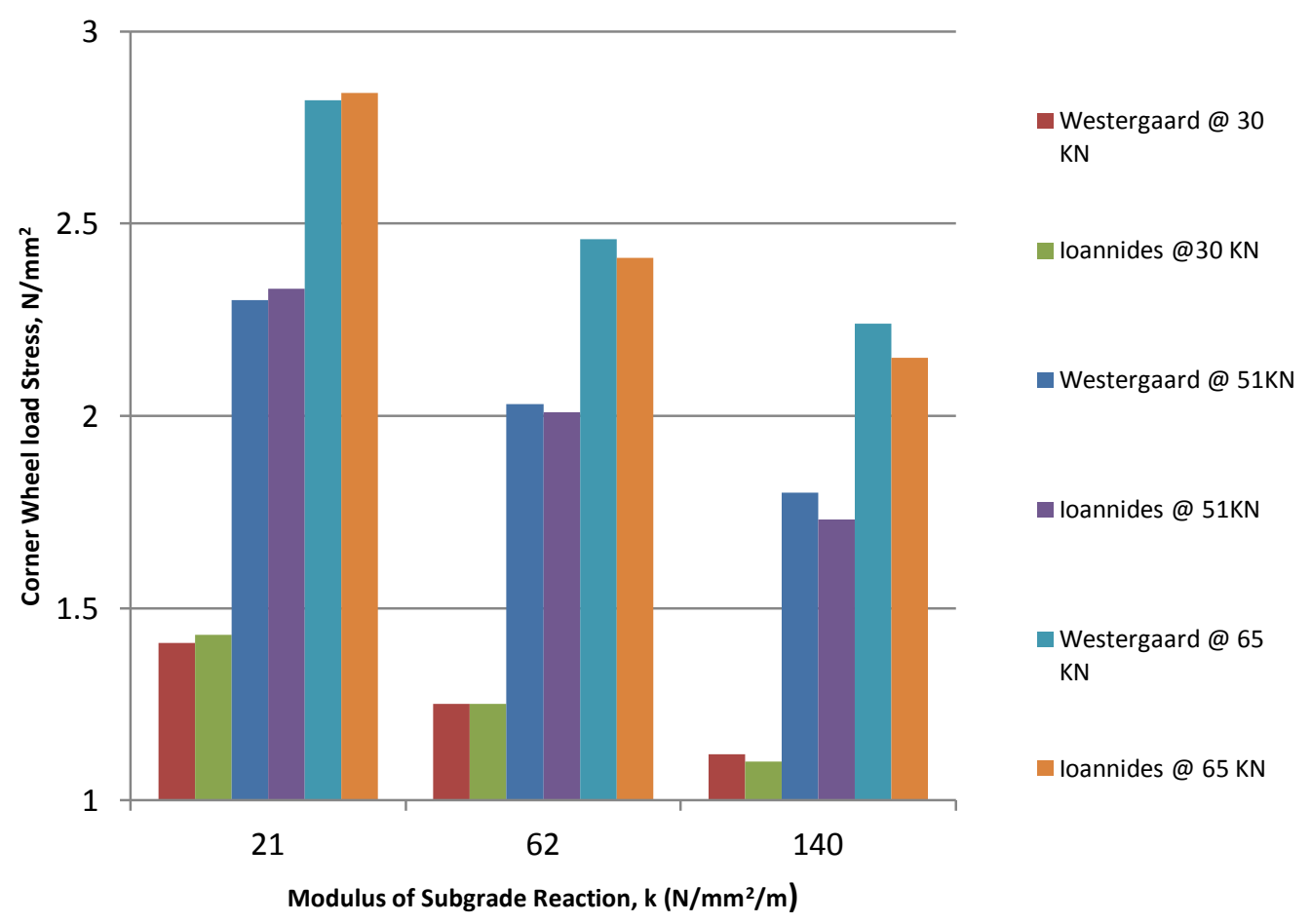

Corner Loading:

For all the 3 loads cases, Ioannides stress for modulus of sub grade reaction $21 \mathrm{~N} / \mathrm{mm}^{2} / \mathrm{m}$ is increasing compared to Westergaard stress.

\subsection{Interior Loading}

In case of interior loading, on bottom surface of slab, the equations proposed by Westergaard to calculate the tensile stress $(\sigma) \&$ vertical displacement $(\Delta)$ are:

$$
\begin{aligned}
& \sigma=\frac{3(1+v) P}{2 \pi h^{2}}\left[\operatorname{Ln} \frac{l}{b}+0.6159\right] \\
& \Delta=\frac{P}{8 k l^{2}}\left\{1+\frac{1}{2 \pi}\left[\operatorname{Ln}\left(\frac{a}{2 l}\right)+0.673\right]\left(\frac{a}{l}\right)^{2}\right\}
\end{aligned}
$$

On further research carried out by Portland Cement Association (PCA), in their procedure of design "Design of Airport Concrete Pavement" [11], equation (8) was adopted to calculate the tensile stress in the bottom fiber of the pavement in the slab centre caused by the load of a given axle.

$\sigma=\frac{0.316 P}{h^{2}}\left(4 \log \frac{l}{b}+1.069\right)$

Using the above equations i.e., eqs. (6), (7), (8) with three treated cases, the values of stress and displacement were tabulated in table 2 .

With $b=a$, if $a \geq 1.724 h$

$\mathrm{b}=\sqrt{1.6 a^{2}+h^{2}}-0.675 h$, if $\mathrm{a}<1.724 \mathrm{~h}$ 
Table2: Stresses and displacements for the Interior loading case using Westergaard and Portland Cement Association (PCA) equations

Case (I):

\begin{tabular}{|c|c|c|c|c|}
\hline & \multirow{3}{*}{$\begin{array}{l}(\mathrm{N}) \\
(\mathrm{MPa})\end{array}$} & \multirow{2}{*}{\multicolumn{3}{|c|}{30000}} \\
\hline \multirow{2}{*}{$\begin{array}{l}\text { Wheel Load } \\
E_{\text {FOUNDATION }}\end{array}$} & & & & \\
\hline & & 30 & 150 & 500 \\
\hline $\mathrm{a}$ & $(\mathrm{m})$ & 0.138 & 0.138 & 0.138 \\
\hline $\mathrm{b}$ & $(\mathrm{m})$ & 0.130 & 0.130 & 0.130 \\
\hline$E_{R C C}$ & (MPa) & 30000 & 30000 & 30000 \\
\hline $\mathrm{k}$ & $(\mathrm{MPa} / \mathrm{m})$ & 21 & 62 & 140 \\
\hline 1 & $(\mathrm{~m})$ & 1.0 & 0.762 & 0.662 \\
\hline$\sigma_{\text {WeSTERGARDS }}$ & $(\mathrm{MPa})$ & 0.92 & 0.81 & 0.72 \\
\hline$\sigma_{P C A}$ & $(\mathrm{~mm})$ & 1.09 & 0.98 & 0.89 \\
\hline$\Delta_{\text {Westergards }}$ & $(\mathrm{mm})$ & 0.17 & 0.09 & 0.067 \\
\hline
\end{tabular}

Case (II):

\begin{tabular}{|c|c|c|c|c|}
\hline Wheel Load & $(\mathrm{N})$ & 51000 & & \\
\hline$E_{\text {FOUNDATION }}$ & (MPa) & 30 & 150 & 500 \\
\hline $\mathrm{a}$ & (m) & 0.152 & 0.152 & 0.152 \\
\hline $\mathrm{b}$ & (m) & 0.142 & 0.142 & 0.142 \\
\hline$E_{R C C}$ & (MPa) & 30000 & 30000 & 30000 \\
\hline $\mathrm{k}$ & $(\mathrm{MPa} / \mathrm{m})$ & 21 & 62 & 140 \\
\hline 1 & (m) & 1.0 & 0.762 & 0.662 \\
\hline$\sigma_{\text {WeSTERGARDS }}$ & (MPa) & 1.86 & 1.66 & 1.51 \\
\hline$\sigma_{P C A}$ & $(\mathrm{~mm})$ & 1.79 & 1.60 & 1.46 \\
\hline$\Delta_{\text {Westergards }}$ & $(\mathrm{mm})$ & 0.29 & 0.17 & 0.11 \\
\hline
\end{tabular}

\begin{tabular}{|c|c|c|c|c|}
\hline \multicolumn{5}{|c|}{ Case (III): } \\
\hline Wheel Load & $(\mathrm{N})$ & 65000 & & \\
\hline$E_{\text {FOUNDATION }}$ & $(\mathrm{MPa})$ & 30 & 150 & 500 \\
\hline $\mathrm{a}$ & $(\mathrm{m})$ & 0.167 & 0.167 & 0.167 \\
\hline $\mathrm{b}$ & $(\mathrm{m})$ & 0.155 & 0.155 & 0.155 \\
\hline$E_{R C C}$ & (MPa) & 30000 & 30000 & 30000 \\
\hline $\mathrm{k}$ & $(\mathrm{MPa} / \mathrm{m})$ & 21 & 62 & 140 \\
\hline 1 & $(\mathrm{~m})$ & 1.0 & 0.762 & 0.662 \\
\hline$\sigma_{W e S T E R G A R D S}$ & (MPa) & 2.34 & 2.09 & 1.95 \\
\hline$\sigma_{P C A}$ & $(\mathrm{~mm})$ & 2.21 & 1.96 & 1.84 \\
\hline$\Delta_{\text {Westergards }}$ & $(\mathrm{mm})$ & 0.38 & 0.22 & 0.12 \\
\hline
\end{tabular}




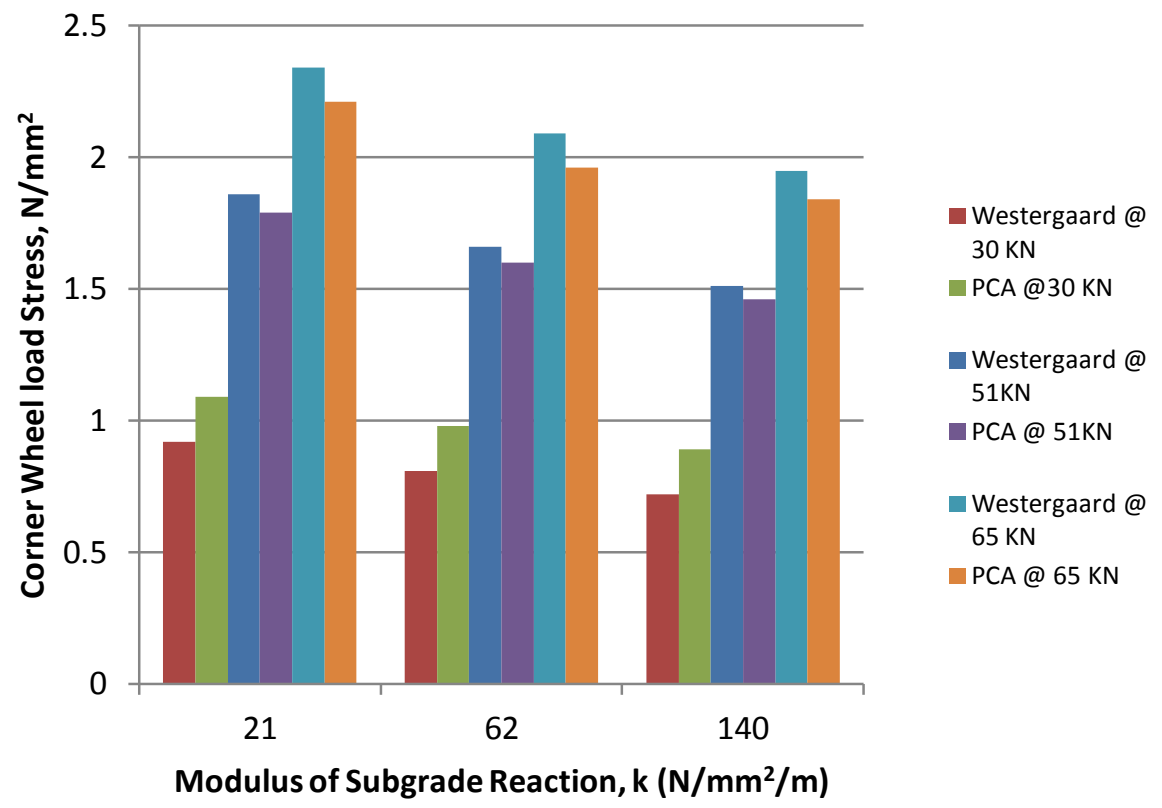

Interior Loading:

PCA stress for $30 \mathrm{kN}$ Wheel load with modulus of sub grade $21 \mathrm{~N} / \mathrm{mm}^{2} / \mathrm{m}$ is increased compared to Westergaard stress.

\subsection{Edge Loading}

For the edge loading case, equations (9), (10) were proposed by Westergaard to calculate the tensile stress and vertical displacement on the bottom surface. These equations are used for calculation of maximum stresses and displacement produced by loads applied on the edges of a rigid slab.

$\sigma=\frac{3(1+v) P}{\pi(3+v) h^{2}}\left[\operatorname{Ln} \frac{E h^{3}}{100 k a^{4}}+1.84-\frac{4 v}{3}+\frac{1-v}{2}+\frac{1.18(1+2 v) a}{l}\right]$

$$
\Delta=\frac{\sqrt{2+1.2 v P}}{\sqrt{E k h^{3}}}\left[1-\frac{(0.76+0.4 v) a}{1}\right]
$$

In the French mechanistic-empirical procedure to design pavements (programmed in the ALIZE software), the above formula was further modified and the maximum tensile stress at the bottom fibers at the edge of the slab is calculated using equation (11).

$$
\sigma=\frac{0.572 P}{h^{2}}\left(4 \log \frac{l}{b}+0.359\right)
$$

Using the above equations i.e., eqs. (9), (10), (11) with three treated cases, the values of stress and displacement were tabulated in table 3 .

Table3: Stresses and displacements for the CORNER loading case using Westergaard and Alize[12] equations

\begin{tabular}{|c|c|c|c|c|}
\hline Wheel Load & (N) & \multicolumn{3}{|l|}{30000} \\
\hline$E_{\text {Foundation }}$ & $(\mathrm{MPa})$ & 30 & 150 & 500 \\
\hline $\mathrm{a}$ & (m) & 0.138 & 0.138 & 0.138 \\
\hline $\mathrm{b}$ & (m) & 0.130 & 0.130 & 0.130 \\
\hline$E_{R C C}$ & (MPa) & 30000 & 30000 & 30000 \\
\hline $\mathrm{k}$ & $(\mathrm{MPa} / \mathrm{m})$ & 21 & 62 & 140 \\
\hline 1 & (m) & 1.0 & 0.762 & 0.662 \\
\hline$\sigma_{\text {Westergard }}$ & (MPa) & 2.14 & 1.85 & 1.63 \\
\hline$\sigma_{A L I Z E}$ & $(\mathrm{MPa})$ & 1.67 & 1.47 & 1.32 \\
\hline$\Delta_{\text {Westergard }}$ & (mm) & 1.10 & 0.61 & 0.39 \\
\hline
\end{tabular}

Case (I):

Case (II):

\begin{tabular}{|l|l|l|l|l|}
\hline Wheel Load & $(\mathrm{N})$ & 51000 & \\
\hline \multicolumn{1}{|c|}{$E_{\text {Foundation }}$} & $(\mathrm{MPa})$ & 30 & 150 & 500 \\
\hline $\mathrm{a}$ & $(\mathrm{m})$ & 0.138 & 0.138 & 0.138 \\
\hline $\mathrm{b}$ & $(\mathrm{m})$ & 0.130 & 0.130 & 0.130 \\
\hline
\end{tabular}




\begin{tabular}{|c|c|c|c|c|}
\hline$E_{R C C}$ & (MPa) & 30000 & 30000 & 30000 \\
\hline $\mathrm{k}$ & $(\mathrm{MPa} / \mathrm{m})$ & 21 & 62 & 140 \\
\hline 1 & (m) & 1.0 & 0.762 & 0.662 \\
\hline$\sigma_{\text {Westergard }}$ & (MPa) & 3.48 & 3.02 & 2.68 \\
\hline$\sigma_{\text {ALIZE }}$ & (MPa) & 2.73 & 2.39 & 2.13 \\
\hline$\Delta_{\text {Westergard }}$ & $(\mathrm{mm})$ & 1.42 & 0.79 & 0.50 \\
\hline
\end{tabular}

Case (III):

\begin{tabular}{|c|c|c|c|c|}
\hline Wheel Load & $(\mathrm{N})$ & \multicolumn{3}{|l|}{65000} \\
\hline$E_{\text {Foundation }}$ & (MPa) & 30 & 150 & 500 \\
\hline son & (m) & 0.167 & 0.167 & 0.167 \\
\hline $\mathrm{b}$ & (m) & 0.155 & 0.155 & 0.155 \\
\hline$E_{R C C}$ & (MPa) & 30000 & 30000 & 30000 \\
\hline $\mathrm{k}$ & $(\mathrm{MPa} / \mathrm{m})$ & 21 & 62 & 140 \\
\hline 1 & (m) & 1.0 & 0.762 & 0.662 \\
\hline$\sigma_{\text {Westergard }}$ & (MPa) & 4.23 & 3.65 & 3.24 \\
\hline$\sigma_{\text {ALIZE }}$ & (MPa) & 3.34 & 2.905 & 2.67 \\
\hline$\Delta_{\text {Westergard }}$ & $(\mathrm{mm})$ & 1.33 & 0.68 & 0.419 \\
\hline
\end{tabular}

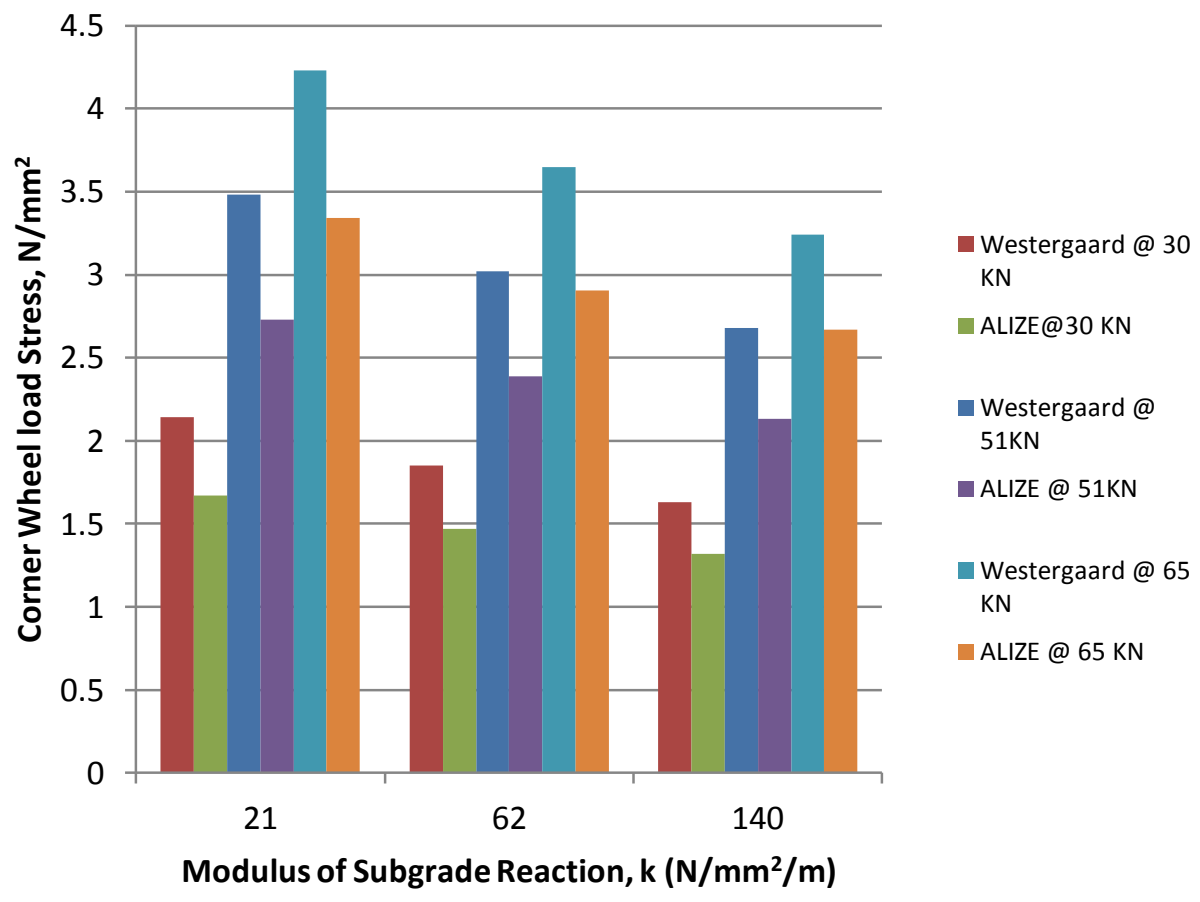

Edge Loading

Alize stress is decreased compared to Westergaard stress at all loads cases \& at all modulus of sub grade reaction values.

\section{INTERPRETATION}

\subsection{Corner \& Interior}

The calculated displacements for the interior loading case were found to be lower compared to corner loading. Stresses due to interior loading were about $65 \%$ of that due to corner loading \& deflections were about $13 \%$.

\subsection{Corner \& Edge}

The calculated displacements for edge loading case were found to be lower compared to corner loading. Stresses due to corner loading were about $65 \%$ of that due to edge loading \& the deflection were about $85 \%$.

\subsection{Interior \& Edge}

The displacements for interior loading were found to be lower compared to edge loading. Stresses due to Interior loading were about $45 \%$ of that due to edge loading \& deflections were about $15 \%$. 


\section{DISCUSSION}

From the above studies, stresses due to edge loading case were higher than those for interior \& corner loading cases. On the other hand, displacements calculated for interior loading is lower compared to corner \& edge loading cases.

\section{CONCLUSION}

The comparison of the stresses \& displacements were predicted using different 2D models. All methods used with all cases analyzed shows that the edge loading case induces higher stresses than interior and corner loading cases and corner loading case induces high deformation than interior and edge loading cases.

\section{REFERENCES}

[1]. M.Zdiri, N.Abriak, J.Neji and M.Ben Ouezdou (2009), Modeling of Stresses \& Strains Distribution in a Roller Compacted Concrete pavement using the computer code "Abaqus", Electronic Journal of Structural Enineering,9

[2]. Mustapha Zdiri, Nor-edine Abriak, Jamel Neji, mongi Ben Ouezdou \& Amara Loulizi (2009), Numerical Modeling of a Roller Compacted Concrete Pavement under vehicular loading, ISSN 1997-1400, International Journal of Pavement Research and Technology 2(5):188-195.

[3]. S.Krishna Rao, P.Sarika, P.Sravana, T.Chandra Sekhara Rao, Evaluation of Properties of roller compacted concrete Pavement, International Journal of Education and Applied Research, ISSN:2348-0033, Vol.4, Issue Spl-2, JAN-JUNE 2014

[4]. S.Krishna Rao, Dr.T.Chandra Sekhara Rao, Dr.P.Sravana, International Journal of Engineering Research and Technology, ISSN: 2278-0181, Vol.2, Issue2, February2013.

[5]. ACI 325 10R-95, State of the Art report on Roller Compacted Concrete Pavements, ACI manual of concrete practice, ACI, USA, 2000:32PP.

[6]. S.Krishna Rao, Dr.T.Chandra Sekhara Rao, Dr. P.Sravana, "Mix Design of Roller Compacted Concrete: An experimental study Using Crushed Stone \& River Sand as Fine Aggregate", National Conference on SCMAT, NIT Warangal, 2013.

[7]. ACI Committee 207.5R-99, "Roller-Compacted Mass Concrete", 1999.

[8]. Huang, Y.H., (2004). Pavement Analysis and Design, $2^{\text {nd }}$ Edition, Prentice Hall, pp. 147-166, University of Kentucky, USA.

[9]. Westergaard, H.M., (1926). Stress in Concrete Pavement Computed by Theoretical Analysis, public Roads, 7(2),pp.25-35.

[10]. Ionnides, A.M., Thompson, M.R., and Barenberg, E.J., (1985). Westergaard Solutions Reconsidered, Transportation Research Record, No. 1043, pp.13-23.

[11]. Portland cement Association, (2004). Guide Specification for Construction of Roller-Compacted Concrete Pavements, IS009.01, 8p. Portland cement Association, USA.
[12]. Jeuffroy, G. and Sauterey, R., (1989). Cours de routes, Chaussee en beton de ciment, pp. 49-79, Presse de I'Ecole Nationale des Ponts et chausses, Paris, France.

[13]. IRC SP: 62-2004(2004), "Guidelines for the Design and Construction of Cement Concrete Pavements for Rural Roads", The Indian Road Congress, 2004.

[14]. ACI 211 3R-02, Guide for Selecting Proportions for No-Slump Concrete, 2002.

[15]. IRC: 58-2002(2002), “Guidelines for Design of Plain Jointed 9. Rigid Pavements for Highways", The Indian Road Congress, 2002.

[16]. ACI Committee 207.5R-99,'Roller Compacted Mass Concrete", 1999.

\section{BIOGRAPHIES}

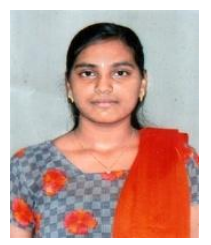

P.Vineela- She received B.E. Degree from S.R.K.R. Engineering College, Bhimavaram. Presently she is pursuing M.Tech in V.R.Siddhartha Engineering College, Vijayawada.

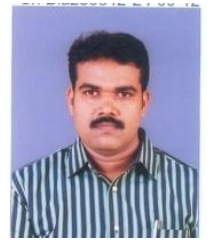

S.Krishna Rao-He Had Received B.Tech Degree from Bapatla Engineering College Bapatla and M.E. from S.G.S. Institute of Technology and Science, Indore. Presently he is pursuing Ph.D from JNTUH, Hyderabad

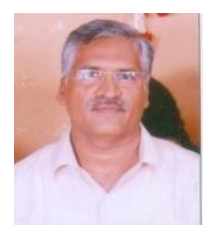

Dr.B.Panduranga Rao, Professor and Dean of V.R.Siddhartha Engineering College, Vijayawada. He had received $\mathrm{Ph}$. D. from Andhra University, Visakhapatnam. His area of interests includes FEM, Structural Dynamics and Earthquake Resistant Design

of Structures.

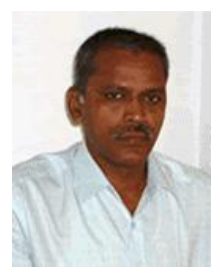

V.Ramesh- He Received M.Tech from ANU, Guntur in Structural Engineering. Presently he is pursuing Ph.D in Civil Engineering of JNTUK, Kakinada. 